\title{
Does Early Egg Consumption Reduce Egg Allergy? Evidence from Randomised Controlled Trials
}

\author{
Nilakshi T Waidyatillake ${ }^{1}$, John A Burgess ${ }^{1}$ and Caroline J lodge ${ }^{* 1,2}$ \\ 1Allergy and Lung Health Unit, Centre for Epidemiology and Biostatistics, Melbourne School of Population and Global Health, \\ The University of Melbourne, VIC, Australia \\ ${ }^{2}$ Murdoch Research Institute, Royal Children's Hospital, Australia \\ *Corresponding author: Caroline Lodge, Allergy and Lung Health Unit, Centre for Epidemiology and Biostatistics, Melbourne \\ School of Population and Global Health, the University of Melbourne, Vic, Australia
}

\begin{tabular}{|c|c|}
\hline ARTICLE INFO & ABSTRACT \\
\hline Received: January 28, 2019 & We refer to the six randomised controlled trials (RCTs) (PETIT; Natsume et al, HEAP; \\
\hline Published: 慧 February 08, 2019 & $\begin{array}{l}\text { Bellach et al, BEAT; Tan et al and STEP; Palmer et al, EAT; Perkin et al, STAR; Palmer et al, } \\
\text { published within the last five years. These trials reported on early egg introduction and risk }\end{array}$ \\
\hline $\begin{array}{l}\text { Citation: Nilakshi T Waidyatillake, } \\
\text { John A Burgess, Caroline J lodge. Does } \\
\text { Early Egg Consumption Reduce Egg }\end{array}$ & $\begin{array}{l}\text { of later egg sensitization and egg allergy at } 12 \text { months of age. Based on these trial results, } \\
\text { it is clear that RCT results need to be critically appraised and interpreted. We found that } \\
\text { the methodological differences among the studies may have influenced the study results. } \\
\text { Therefore, critical interpretation of RCT results is required to understand the evidence. }\end{array}$ \\
\hline
\end{tabular}

Keywords: Randomised controlled trials; Egg; Sensitisation; Allergy

\section{Introduction}

We refer to the six randomised controlled trials (RCTs) PETIT; Natsume et al. [1], HEAP; Bellach et al. [2], BEAT; Tan et al. [3] and STEP; Palmer et al. [4], EAT; Perkin et al. [5], STAR; Palmer et al. [6] published within the last five years. The trials reported on early egg introduction and risk of later egg sensitisation and allergy at 12 months of age. Although these six trials were very similar in several respects, we have concerns regarding the consistency of the findings. The Japanese PETIT trial was the only one to find a protective effect for egg allergy diagnosed using oral food challenge testing (OFC). Although the EAT and STAR trials concluded that early introduction of egg was protective against food allergy, neither showed good evidence on OFC testing. In terms of sensitisation, the BEAT trial found reduced sensitisation when whole egg was introduced to high risk infants. The STEP and HEAP found no protection for either sensitisation or food allergy.

RCTs provide the highest level of evidence for a causal effect from an intervention [7]. However, belief in the RCT as a study design may lead to theresults being accepted as unarguable evidence and a failure to critically appraise individual studies. This can lead to confusion when similar RCTs present conflicting results as is the case here. There are several methodological differences between the studies which may have influenced the results. PETIT was based on high risk children in Japan. The other studies on high allergy risk populations, the BEAT, STEP and STAR, all used Australian birth cohorts, and the allergy risk was defined differently. In the BEAT study, high risk was defined as any immediate family member (father, mother, older sibs) with food allergy, asthma, atopic eczema or allergic rhinitis. In STEP it was based on the "atopic status" of the mother only (medically diagnosed allergic disease with sensitisation to at least one common aero allergen), and results were adjusted for paternal allergic disease. The STAR trial recruited babies with severe eczema. In all three trials the intervention was similar (whole egg) and, all assessed the outcome at 12 months. However, the intervention timing and duration differed. In STAR and BEAT the intervention began at 4 and ended at 8 months with a duration of 4 months. In STEP, the intervention began at 4.56 months continuing until 10 months with a variable duration of 4.5-6 months. They also differed with respect to analysis. Although both BEAT and STEP provided an intention-to-treat analysis, STEP adjusted for baseline factors which appeared different between the groups while BEAT controlled only for region of origin of parents. All 3 trials may have been underpowered (Table 1). The STEP 
trial which reportedly failed to reach the planned sample size was almost twice the sample size of BEAT and 10 times the size of STAR.

In contrast, the HEAP and EAT trials were selected from the general population. The intervention in HEAP was egg white, as opposed to whole egg, and in EAT it was a combination of 6 aller- genic foods, making it distinctly different from all the other trials. In HEAP egg introduction commenced at 4-6 months and continued until 12 months of age with an intervention duration of 6-8 months, substantially longer than the other trials, and extending into a different developmental period of infancy (12 months as opposed to 8 or 10 months in BEAT and STEP and 4 to 8 months in STAR).

Table 1: A comparison of the methodology of included trials and the message from each trial.

\begin{tabular}{|c|c|c|c|c|c|c|}
\hline & $\begin{array}{c}\text { PETIT Trial } \\
\text { Natsume et al. [1] }\end{array}$ & $\begin{array}{c}\text { HEAP Trial } \\
\text { Bellach et al. [2] }\end{array}$ & $\begin{array}{l}\text { BEAT Trial } \\
\text { Tan et al. [3] }\end{array}$ & $\begin{array}{c}\text { STEP Trial } \\
\text { Palmer et al. [4] }\end{array}$ & $\begin{array}{c}\text { EAT trial } \\
\text { Perkin et al. [5] }\end{array}$ & $\begin{array}{c}\text { STAR Trial } \\
\text { Palmer et al. [4] }\end{array}$ \\
\hline Country & Japan & Germany & Australia & Australia & United Kingdom & Australia \\
\hline $\begin{array}{l}\text { Clinical trial } \\
\text { registry number }\end{array}$ & UMIN: 000008673 & DRKS: 00005668 & $\begin{array}{c}\text { ACTRN: } \\
12611000535976\end{array}$ & ACTRN: 12610000388011 & $\begin{array}{l}\text { ISRCTN: } \\
14254740\end{array}$ & $\begin{array}{c}\text { ACTRN: } \\
12609000415202\end{array}$ \\
\hline Population & High risk population & General population & $\begin{array}{l}\text { High risk } \\
\text { population }\end{array}$ & High risk population & $\begin{array}{c}\text { General } \\
\text { population }\end{array}$ & High risk population \\
\hline $\begin{array}{l}\text { Inclusion } \\
\text { criteria }\end{array}$ & $\begin{array}{c}\text { 4-5 months of age } \\
\text { With Atopic } \\
\text { dermatitis } \\
\text { Born after } 38 \text { weeks } \\
\text { of gestation } \\
\text { Not ingested eggs no } \\
\text { immediate allergic } \\
\text { reaction to eggs or } \\
\text { not having severe } \\
\text { illnesses }\end{array}$ & $\begin{array}{c}\text { Gestational age }> \\
34 \text { weeks } \\
\text { Birth weight } \\
>2.5 \mathrm{Kg} \\
\text { Maternal age }>18 \\
\text { year } \\
\text { Sufficient language } \\
\text { skills }\end{array}$ & $\begin{array}{l}\text { Healthy } \\
\text { Full term }\end{array}$ & $\begin{array}{c}\text { Singleton infants } \\
\text { Children without allergic } \\
\text { diseases such as eczema } \\
\text { Eggs were not introduced } \\
\text { before the age of } 4 \text { months } \\
\text { Children without } \\
\text { congenital or } \\
\text { developmental disorders } \\
>35 \text { weeks of gestation } \\
\text { Birth weight between } \\
2.0-4.5 \mathrm{Kg}\end{array}$ & $\begin{array}{l}\text { Singleton infants } \\
\text { Three months } \\
\text { of age } \\
\text { Exclusively } \\
\text { breastfed }\end{array}$ & $\begin{array}{l}\text { Singleton infants } \\
\text { With moderate to severe } \\
\text { eczema } \\
\text { Eggs or solids introduced } \\
\text { before } 4 \text { months of age } \\
\text { were excluded }\end{array}$ \\
\hline $\begin{array}{l}\text { High-risk } \\
\text { population } \\
\text { definition }\end{array}$ & $\begin{array}{c}\text { Atopic dermatitis } \\
\text { diagnosed based on } \\
\text { Hannifin and Rajka } \\
\text { criteria }\end{array}$ & NA & $\begin{array}{l}\text { At least one first } \\
\text { degree relative } \\
\text { with atopic } \\
\text { disease (food } \\
\text { allergy, asthma, } \\
\text { atopic eczema, or } \\
\text { allergic rhinitis) }\end{array}$ & $\begin{array}{l}\text { Maternal atopy diagnosed } \\
\text { as history of a medically } \\
\text { diagnosed allergic disease } \\
\text { with sensitisation to } \\
\text { at least one common } \\
\text { aeroallergen }\end{array}$ & NA & $\begin{array}{l}\text { Moderate to severe } \\
\text { eczema determined by } \\
\text { using a standardized } \\
\text { SCORAD }\end{array}$ \\
\hline $\begin{array}{l}\text { Sample size } \\
\text { (intervention/ } \\
\text { control) }\end{array}$ & $\begin{array}{l}\text { Intervention: } 73 \\
\text { Control: } 74\end{array}$ & $\begin{array}{l}\text { Intervention: } 142 \\
\text { Control: } 156\end{array}$ & $\begin{array}{l}\text { Intervention: } 122 \\
\text { Control: } 122\end{array}$ & $\begin{array}{l}\text { Intervention: } 407 \\
\text { Control: } 413\end{array}$ & $\begin{array}{l}\text { Intervention } \\
\qquad: 567 \\
\text { Control :595 }\end{array}$ & $\begin{array}{c}\text { Intervention :49 } \\
\text { Control:37 }\end{array}$ \\
\hline $\begin{array}{l}\text { Method used } \\
\text { for exclusion } \\
\text { of sensitized } \\
\text { infants at } \\
\text { baseline }\end{array}$ & $\begin{array}{l}\text { NA (IgE for Hen's egg } \\
\text { was tested but has } \\
\text { not led to exclusion) }\end{array}$ & $\begin{array}{l}\text { Hen's egg specific } \\
\text { IgE } \geq 0.35 \text { Kilounits } \\
\text { Number excluded } \\
\text { 23(Due to } \\
\text { increased IgE) }\end{array}$ & $\begin{array}{l}\text { SPT to commercial } \\
\text { egg white of } 2 \mathrm{~mm} \\
\text { or greater } \\
\text { Number excluded } \\
13 \text { (70\% of these } \\
\text { had eczema) }\end{array}$ & $\begin{array}{c}\text { Infants who had a history } \\
\text { of allergic disease } \\
\text { Number excluded } 396\end{array}$ & $\begin{array}{l}\text { SPT greater than } \\
\text { zero and OFC to } \\
\text { check whether } \\
\text { they are allergic } \\
\text { to exclude } \\
\text { Number } \\
\text { excluded } 16 \\
\text { (50\% had major } \\
\text { health issues) }\end{array}$ & $\begin{array}{l}\text { NA (Although blood } \\
\text { samples were tested } \\
\text { for egg specific IgE and } \\
\text { IgG this had not led to } \\
\text { exclusion) }\end{array}$ \\
\hline
\end{tabular}




\begin{tabular}{|c|c|c|c|c|c|c|}
\hline $\begin{array}{l}\text { Randomisation } \\
\text { procedure }\end{array}$ & $\begin{array}{l}\text { Double blind } \\
\text { 1:1 randomisation } \\
\text { Using permuted } \\
\text { blocks of } 4 \\
\text { randomisation } \\
\text { and participants } \\
\text { stratified based on } \\
\text { institution and sex }\end{array}$ & $\begin{array}{l}\text { Double blind } \\
\text { 1:1 randomisation } \\
\text { at a single site }\end{array}$ & $\begin{array}{l}\text { Double blind } \\
\text { randomisation } \\
\text { based on } \\
\text { permuted blocks } \\
\text { stratified by sex }\end{array}$ & $\begin{array}{c}\text { Double blind } \\
\text { randomly permuted } \\
\text { blocks } 4,6 \text { and } 8 \text { with } \\
\text { stratification for city, infant } \\
\text { sex, and feeding mode }\end{array}$ & $\begin{array}{l}\text { Double blind } \\
\text { randomly } \\
\text { allocated } 1: 1 \\
\text { to early and } \\
\text { standard } \\
\text { introduction }\end{array}$ & $\begin{array}{c}\text { Double blind } \\
\text { random allocation } \\
\text { stratified by infant } \\
\text { sex and feeding mode } \\
\text { (breastfed or formula fed } \\
>200 \mathrm{ml} \text { per day) }\end{array}$ \\
\hline \multirow{6}{*}{ Intervention } & $\begin{array}{l}\text { Type: Boiled whole } \\
\text { hen's egg powder }\end{array}$ & $\begin{array}{l}\text { Type: Pasteurized } \\
\text { Raw hen's egg } \\
\text { white powder }\end{array}$ & $\begin{array}{l}\text { Type: Pasteurized } \\
\text { whole hen's egg } \\
\text { powder }\end{array}$ & $\begin{array}{l}\text { Type: pasteurized raw } \\
\text { whole hen's egg powder }\end{array}$ & $\begin{array}{l}\text { Type: Allergen } \\
\text { protein (peanut, } \\
\text { cooked whole } \\
\text { hen's egg, cow's } \\
\text { milk, sesame, } \\
\text { white fish and } \\
\text { wheat) }\end{array}$ & $\begin{array}{l}\text { Type: Pasteurized raw } \\
\text { whole hen's egg powder }\end{array}$ \\
\hline & $\begin{array}{l}\text { Quantity: } 25 \mathrm{mg} \text { of } \\
\text { hen's egg protein } \\
\text { daily }\end{array}$ & $\begin{array}{l}\text { Quantity: } 2.5 \mathrm{~g} \\
\text { hen's egg protein } \\
\text { (building up over } \\
\text { three weeks }\end{array}$ & $\begin{array}{l}\text { Quantity: } 0.35 \mathrm{~g} \\
\text { egg protein }\end{array}$ & $\begin{array}{l}\text { Quantity: } 0.4 \mathrm{~g} \text { egg protein } \\
\text { daily }(0.9 \mathrm{~g} \text { egg powder } \\
(1 / 2 \text { egg per week })\end{array}$ & Quantity: 2 g & $\begin{array}{c}\text { Quantity: } 0.9 \mathrm{~g} \text { egg } \\
\text { protein equivalent to } 1 / 2 \\
\text { of an egg }\end{array}$ \\
\hline & Start: 6 months & $\begin{array}{l}\text { Start: } 4 \text { to } 6 \\
\text { months }\end{array}$ & Start: 4 months & Start: 4-6.5 months & Start: 3 months & Start: 4 months \\
\hline & End: 12 months & End: 12 months & End: 8 months & End:10 months & End:6 months & End: 8 months \\
\hline & $\begin{array}{c}\text { Intervention } \\
\text { duration: } 6 \text { months }\end{array}$ & $\begin{array}{l}\text { Intervention } \\
\text { duration: 6-8 } \\
\text { months }\end{array}$ & $\begin{array}{l}\text { Intervention } \\
\text { duration: } 4 \\
\text { months }\end{array}$ & $\begin{array}{l}\text { Intervention duration: } 4.5- \\
6 \text { months }\end{array}$ & $\begin{array}{l}\text { Intervention } \\
\text { duration: } 3 \\
\text { months }\end{array}$ & $\begin{array}{l}\text { Intervention duration: } 4 \\
\text { months }\end{array}$ \\
\hline & Frequency: daily & $\begin{array}{l}\text { Frequency- three } \\
\text { times a week }\end{array}$ & Frequency- daily & Frequency- daily & $\begin{array}{l}\text { Frequency: } \\
\text { twice weekly }\end{array}$ & Frequency: daily \\
\hline Control & $\begin{array}{l}\text { Type- pumpkin } \\
\text { powder }\end{array}$ & Type: Rice powder & Type: Rice powder & Type: Rice powder & $\begin{array}{l}\text { Type-Breast } \\
\text { milk }\end{array}$ & Type: Rice powder \\
\hline $\begin{array}{l}\text { When } \\
\text { encouraged to } \\
\text { introduce egg to } \\
\text { controls }\end{array}$ & 12 months & 12 months & 8 months & 10 months & 6 months & 8 months \\
\hline $\begin{array}{l}\text { Age at outcome } \\
\text { assessment } \\
\text { And outcome } \\
\text { types }\end{array}$ & $\begin{array}{l}12 \text { months: } \\
\text { Sensitisation: } \\
\text { IgE, IgG1, IgG4, and } \\
\text { IgA } \geq 0.35 \mathrm{Ku} \\
\text { Food allergy } \\
\text { Oral food challenge } \\
\text { (open labelled) }\end{array}$ & $\begin{array}{c}12 \text { months: } \\
\text { Sensitisation } \\
\text { IgE levels } \geq 0.35 \mathrm{Ku} \\
\text { as egg allergy } \\
\text { Food allergy } \\
\text { Oral food } \\
\text { challenge (Double } \\
\text { blind placebo } \\
\text { controlled }\end{array}$ & $\begin{array}{c}12 \text { months: } \\
\text { Sensitisation } \\
\text { EW-SPT responses } \\
\text { of 3mm or greater } \\
\text { as egg allergy } \\
\text { Food allergy } \\
\text { Oral food } \\
\text { challenge (Double } \\
\text { blind placebo } \\
\text { controlled }\end{array}$ & $\begin{array}{c}12 \text { months: Sensitisation } \\
\text { IgE levels } \geq 0.35 \mathrm{Ku} \text { as egg } \\
\text { allergy SPT } 3 \mathrm{~mm} \text { or greater } \\
\text { Food allergy } \\
\text { Oral food challenge (open } \\
\text { labelled) }\end{array}$ & $\begin{array}{l}12 \text { months and } \\
36 \text { months } \\
\text { Sensitisation } \\
\text { SPT >5mm or } \\
\text { greater } \\
\text { Food allergy } \\
\text { Oral food } \\
\text { challenge } \\
\text { (Double } \\
\text { blind placebo } \\
\text { controlled }\end{array}$ & $\begin{array}{c}8 \text { and } 12 \text { months } \\
\text { Sensitisation } \\
\text { IgE and IgG } \geq 0.35 \mathrm{Ku} \text { for } \\
\text { tested allergens } \\
\text { Food allergy } \\
\text { Oral food challenge (open } \\
\text { labelled) }\end{array}$ \\
\hline $\begin{array}{l}\text { Did the authors } \\
\text { consider } \\
\text { and adjust } \\
\text { for potential } \\
\text { imbalance in } \\
\text { baseline factors } \\
\text { or adjust for } \\
\text { other factors }\end{array}$ & $\begin{array}{l}\text { Adjusted for allergic } \\
\text { history of father and } \\
\text { mother and start of } \\
\text { solid foods }\end{array}$ & - & $\begin{array}{l}\text { Fathers region of } \\
\text { birth (Australian } \\
\text { or New Zealand) }\end{array}$ & $\begin{array}{c}\text { Adjusted for city, infant sex, } \\
\text { breast-feeding status, and } \\
\text { paternal history of allergic } \\
\text { disease }\end{array}$ & Age & $\begin{array}{c}\text { Checked for baseline } \\
\text { disparities and there were } \\
\text { no significant differences }\end{array}$ \\
\hline
\end{tabular}




\begin{tabular}{|c|c|c|c|c|c|c|}
\hline $\begin{array}{l}\text { Non- } \\
\text { participants/ } \\
\text { Participants not } \\
\text { completing } \\
\text { Adverse } \\
\text { reactions }\end{array}$ & $\begin{array}{l}119 \text { excluded at } \\
\text { randomisation } \\
37 \text {-no atopic } \\
\text { dermatitis } \\
\text { 69-parental decline } \\
\text { 13- not registered } \\
\text { During the follow up } \\
24 \text { form the placebo } \\
\text { arm and the } 27 \text { from } \\
\text { the intervention arm } \\
\text { were excluded } \\
\text { None have stopped } \\
\text { due to the adverse } \\
\text { reactions to trial } \\
\text { powder }\end{array}$ & $\begin{array}{l}23 \text { at } \\
\text { randomisation } \\
42 \text { in the } \\
\text { intervention arm } \\
\text { and the } 43 \text { in the } \\
\text { control arm were } \\
\text { lost } \\
18 \text { from the } \\
\text { intervention arm } \\
\text { excluded due } \\
\text { to inadequate } \\
\text { or impossible } \\
\text { adherence to the } \\
\text { study powder }\end{array}$ & $\begin{array}{c}28 \text { at } \\
\text { randomisation } \\
14 \text { reacted to } \\
\text { egg powder and } \\
\text { stopped (14/152) } \\
7 \text { lost to follow-up } \\
\text { in the intervention } \\
\text { arm and } 8 \text { lost to } \\
\text { follow up in the } \\
\text { control arm } \\
14 \text { infants reacted } \\
\text { to study powder } \\
\text { and did not } \\
\text { continue }\end{array}$ & $\begin{array}{l}1200 \text { at randomisation } \\
25 \text { in the intervention arm } \\
\text { and the } 6 \text { in the control } \\
\text { arm had reactions to study } \\
\text { powder } \\
12 \text { in each arm was lost to } \\
\text { follow-up } \\
6 \text { infants had reactions to } \\
\text { study powder }\end{array}$ & $\begin{array}{l}1303 \text { were } \\
\text { randomised } \\
\text { and } 651 \text { were } \\
\text { in the standard } \\
\text { introduction } \\
\text { group and } 652 \\
\text { were in the early } \\
\text { introduction } \\
\text { group. From } \\
\text { the standard } \\
\text { introduction } \\
\text { group } 56 \text { had } \\
\text { missing data } 7 \\
\text { has exceeded } \\
\text { the visit window } \\
\text { and } 5 \text { could not } \\
\text { be evaluated } \\
\text { from the early } \\
\text { introduction } \\
\text { group } 81 \text { had } \\
\text { missing data } \\
\text { None have } \\
\text { stopped due to } \\
\text { adverse effects }\end{array}$ & $\begin{array}{l}9 \text { did not attend the } \\
\text { final appointment } 4 \text { as } \\
\text { their parents were busy } \\
\text { from this } 1 \text { was in the } \\
\text { rice group, two did not } \\
\text { like the rice powder, I } \\
\text { had repeated illnesses, I } \\
\text { moved overseas, and I did } \\
\text { not want to have the raw } \\
\text { egg challenge) } \\
4 \text { children developed } \\
\text { severe adverse reactions } \\
\text { due to the study powder }\end{array}$ \\
\hline $\begin{array}{l}\text { Results- } \\
\text { sensitisation }\end{array}$ & $\begin{array}{l}\text { ITA } 8 \% \text { of the } \\
\text { intervention group } \\
\text { and } 38 \% \text { of the } \\
\text { control group } \\
\text { was sensitized } \\
\text { (p=0.0001) } \\
\text { PPA } 4 \% \text { of the } \\
\text { intervention group } \\
\text { and } 38 \% \text { of the } \\
\text { control group } \\
\text { was sensitized } \\
9 p<0.0001 \text { ) }\end{array}$ & $\begin{array}{l}\text { ITA } 5.6 \% \text { in the } \\
\text { intervention group } \\
\text { and } 2.6 \% \text { of the } \\
\text { placebo group was } \\
\text { sensitised to egg } \\
\text { (p=0.24) } \\
\text { PPA } 4.8 \% \text { in the } \\
\text { intervention group } \\
\text { and } 2.6 \% \text { of the } \\
\text { placebo group } \\
\text { was sensitised } \\
\text { to egg RR,1.84 } \\
95 \% \text { CI:0.53,6.37 } \\
\text { (p=0.35) }\end{array}$ & $\begin{array}{l}\text { ITA } 10.7 \% \text { in } \\
\text { the intervention } \\
\text { group and } 20.5 \% \\
\text { of the placebo } \\
\text { group was } \\
\text { sensitised to egg } \\
\text { (OR) of } 0.46 \text { (95\% } \\
\text { CI, } 0.22-0.95 ; \\
\text { p=0.03 } \\
\text { PPA- (OR, } 0.24 \text {; } \\
95 \% \text { CI, } 0.09-0.61 \text {; } \\
\text { P } 0.015) .\end{array}$ & $\begin{array}{l}\text { ITA } 7 \% \text { of the intervention } \\
\text { group and } 10.3 \% \text { of control } \\
\text { group was sensitised to } \\
\text { egg (OR of } 0.7595 \% \mathrm{CI} \text {, } \\
0.48,1.17) \mathrm{p}=0.20 \mathrm{SPT} \\
\text { results- } 0.77(0.54-1.10) \\
\text { p=0.15 } \\
\text { PPA- The per-protocol } \\
\text { analysis found a lower } \\
\text { percentage of infants in } \\
\text { the egg group, } 9 \text { of } 305 \\
(3.0 \%) \text {, compared with the } \\
\text { control group, 31 of } 312 \\
(9.9 \%) \text { (aRR, } 0.32 ; 95 \% \mathrm{CI} \text {, } \\
0.16-0.65 ; \mathrm{P} 0.002), \text { had } \\
\text { IgE-mediated egg allergy }\end{array}$ & $\begin{array}{l}\text { ITA- at } 12 \\
\text { months } 13 \% \\
\text { in the standard } \\
\text { introduction } \\
\text { group and } \\
10.4 \% \text { in } \\
\text { the early } \\
\text { introduction } \\
\text { group ( } \mathrm{p}=0.17 \text { ) } \\
\text { and at } 36 \\
\text { months } 6.2 \% \\
\text { in the standard } \\
\text { introduction } \\
\text { group and } 5.1 \% \\
\text { in the early } \\
\text { introduction } \\
\text { group ( } \mathrm{p}=0.43) .\end{array}$ & $\begin{array}{l}\text { ITA- } 45 \% \text { in the egg } \\
\text { group and the } 63 \% \text { of } \\
\text { the control group was } \\
\text { sensitised to egg (RR:0.72 } \\
95 \% \text { CI, } 0.47,1.09 \text { ) p=0.12 } \\
\text { PPA - at } 12 \text { months } \\
12.5 \% \text { in the standard } \\
\text { introduction group } \\
\text { and } 6.1 \% \text { in the early } \\
\text { introduction group } \\
\text { (p=0.009) and at } 36 \\
\text { months 6.3\% in the } \\
\text { standard introduction } \\
\text { group and 3.3\% in the } \\
\text { early introduction group } \\
(\mathrm{p}=0.10)\end{array}$ \\
\hline $\begin{array}{l}\text { Results- Oral } \\
\text { food challenge }\end{array}$ & $\begin{array}{l}\text { At } 12 \text { months } \\
\text { Oral food challenge } \\
9 \% \text { of the egg } \\
\text { group and } 38 \% \\
\text { of the placebo } \\
\text { group (OR:0.083, } \\
\text { 95\%CI:0.023,0.297). } \\
\text { IgE levels in the ITA } \\
\text { among the non- } \\
\text { sensitised group } \\
\text { placebo vs egg the } \\
\text { p=0.31 Among the } \\
\text { sensitised group } \\
0.001 .\end{array}$ & $\begin{array}{l}\text { At } 12 \text { months } \\
\text { Oral food challenge } \\
2.1 \% \text { from the } \\
\text { intervention group } \\
\text { and the } 0.76 \% \text { of } \\
\text { the control group } \\
\text { had a positive } \\
\text { challenge and } \\
\text { there was no } \\
\text { difference between } \\
\text { groups }\end{array}$ & $\begin{array}{l}\text { At } 12 \text { months - } \\
\text { Oral food } \\
\text { challenge or } \\
\text { described reaction } \\
\text { to powder } 8 / 24 \\
\text { vs } 13 / 124- \\
\text { no difference } \\
\text { between groups }\end{array}$ & $\begin{array}{l}\text { At } 12 \text { months } \\
\text { Oral food challenge } 7.7 \% \text { of } \\
\text { the egg group and the } 41 \% \\
\text { of the control group had } \\
\text { a positive egg challenge } \\
\text { (OR: } 0.79(95 \% \mathrm{CI}-0.51,1.21) \\
\text { p= } 0.28 \text { no difference } \\
\text { between groups }\end{array}$ & $\begin{array}{l}\text { In the standard } \\
\text { introduction } \\
\text { group 5.4\% and } \\
3.7 \% \text { in the early } \\
\text { introduction } \\
\text { group }(\mathrm{p}=0.17 \text { ). }\end{array}$ & $\begin{array}{l}\text { At } 12 \text { months- } \\
\text { Oral food challenge } \\
\text { 33\% had a positive } \\
\text { egg challenge }\end{array}$ \\
\hline $\begin{array}{l}\text { Further } \\
\text { analyses } \\
\text { available }\end{array}$ & $\begin{array}{l}\text { In the PPA among } \\
\text { the non-sensitised } \\
\text { group placebo vs egg } \\
\text { it is } \mathrm{p}=0.063 \text { and in } \\
\text { the sensitised group } \\
\mathrm{p}=0.00251 \% \text { from } \\
\text { the control group }\end{array}$ & $\begin{array}{l}\text { Egg challenge test } \\
\text { Among the } \\
\text { children with } \\
\text { eczema hens' egg } \\
\text { specific IgE was } \\
\text { high at baseline } \\
\text { (p,0.001) }\end{array}$ & $\begin{array}{l}\text { Intervention } \\
\text { group higher } \\
\text { IgG4 an higher } \\
\text { IgG4/IgE } \\
\text { ratios(p<0.0001) } \\
\text { No difference } \\
\text { in the IgE levels } \\
\text { between the } \\
\text { groups }\end{array}$ & $\begin{array}{c}\text { Egg-specific IgG4 levels } \\
\text { were substantially } \\
\text { higher in the egg group at } \\
12 \text { months (median, } 1.22 \\
\text { mgA/L vs } \\
\text { control } 0.07 \mathrm{mgA} / \mathrm{L} ; \mathrm{P}< \\
.0001 \text { ). }\end{array}$ & $\begin{array}{c}\text { Adjusted } \\
\text { per protocol } \\
\text { analysis }-5.2 \% \\
\text { in the standard } \\
\text { introduction } \\
\text { group and } 1.4 \% \\
\text { in the early } \\
\text { introduction } \\
\text { group ( } \mathrm{p}=0.02 \text { ). }\end{array}$ & $\begin{array}{c}\text { Lower proportion in } \\
\text { the egg group had IgE } \\
\text { mediated egg allergy at } \\
12 \text { months in the egg } \\
\text { group (RR: } 0.65(0.38,1.11) \\
\mathrm{p}=0.11\end{array}$ \\
\hline
\end{tabular}




\begin{tabular}{|c|c|c|c|c|c|}
\hline & $\begin{array}{c}\text { Heated egg } \\
\text { introduction to } \\
\text { Coverall } \\
\text { high risk children } \\
\text { the trial }\end{array}$ & $\begin{array}{c}\text { No evidence of } \\
\text { protection } \\
\text { development of egg } \\
\text { allergy. }\end{array}$ & $\begin{array}{c}\text { E protective effect } \\
\text { towards egg } \\
\text { sensitisation }\end{array}$ & $\begin{array}{c}\text { No evidence of protection } \\
\text { introduction of } \\
\text { allergenic food } \\
\text { is protective } \\
\text { against food } \\
\text { allergy }\end{array}$ & $\begin{array}{c}\text { can be achieved by early } \\
\text { regular introduction } \\
\text { of eggs in infants with } \\
\text { eczema }\end{array}$ \\
\hline
\end{tabular}

Note: NA: not applicable.

Results from HEAP, although not significant at the 5\% level, suggested an increased risk of sensitisation to egg in the intervention group. Similarities in results from STEP and HEAP (no associations found) may be related to the longer duration of the intervention in these two trials.

A major difference between the trials which may explain the different outcomes is the timing of egg introduction to the control groups with respect to the commonly measured outcome time of 12 months. BEAT and STAR controls were encouraged to consume egg from 8 months, STEP controls from 10 months, and HEAP and PETIT controls from 12 months. This difference may have influenced the timing of IgE response to egg introduction in the controls which may in turn have changed the magnitude and direction of association when compared to the intervention group. For example, if children in the HEAP trial had not been exposed to egg prior to egg allergy testing, then they may appear less "sensitised" compared to exposed populations.

In summary, the methodological differences which may have resulted in different findings include: the trial population, the sample size, the start and end date of the intervention, the treatment of the control group with respect to the intervention and how the outcomes were analysed.

The main drawback of RCT's is external validity or how generalizable the trial results are [7]. The best way to overcome questions related to external validity is to recruit a representative sample form the general population. Therefore, a random selection of a sample from the general population is the first step followed by randomisation of the enrolled participants. Based on these two factors it can be decided whether the results are truly generalizable and how the results could be incorporated into policy. Furthermore, there is evidence that the external validity determines where the trial sits truly in the evidence hierarchy [7].

Evidence from RCTs cannot be taken at face value. All evidence, regardless of study type, needs to be critically evaluated with respect to methodology even though RCT's are considered the highest level of evidence. We suggest that the evidence presented by these RCTs is insufficient to confirm that early egg consumption reduces future egg sensitisation and allergy. Larger trials based on the general population accounting for baseline disparities among the trial arms should be our future focus.

\section{References}

1. Natsume O, Kabashima S, Nakazato J, Yamamoto Hanada K, Narita M, et al. (2017) Two-step egg introduction for prevention of egg allergy in high-risk infants with eczema (PETIT): a randomized, double-blind, placebo-controlled trial. The Lancet 389(10066): 276-286.

2. Bellach J, Schwarz V, Ahrens B, Trendelenburg V, Aksünger Ö, et al. (2017) Randomized placebo-controlled trial of hen's egg consumption for primary prevention in infants. J Allergy Clin Immunol 139(5): 15911599.

3. Wei-Liang Tan J, Valerio C, Barnes EH, Turner PJ, Van Asperen PA, et al. (2017) A randomized trial of egg introduction from 4 months of age in infants at risk for egg allergy. J Allergy Clin Immunol 139(5): 1621-628.

4. Palmer DJ, Sullivan TR, Gold MS, Prescott SL, Makrides M (2017) Randomized controlled trial of early regular egg intake to prevent egg allergy. J Allergy Clin Immunol 139(5): 1600-1607.

5. Perkin MR, Logan K, Tseng A, Bunmi Raji, Salma Ayis, et al. (2016) Randomized Trial of Introduction of Allergenic Foods in Breast-Fed Infants. New England Journal of Medicine 374: 1733-1743.

6. Palmer DJ, Metcalfe J, Makrides M, Gold MS, Quinn P, et al. (2013) Early regular egg exposure in infants with eczema: A randomized controlled trial. J Allergy Clin Immunol 132(2): 387-392.

7. Stuart EA, Bradshaw CP, Leaf PJ (2015) Assessing the Generalizability of Randomized Trial Results to Target Populations. Prevention science : the official journal of the Society for Prevention Research 16(3): 475-485.

\section{ISSN: 2574-1241}

DOI: 10.26717.BJSTR.2019.14.002526

Caroline Lodge. Biomed J Sci \& Tech Res

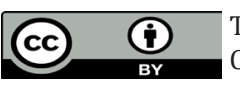

This work is licensed under Creative Commons Attribution 4.0 License

Submission Link: https://biomedres.us/submit-manuscript.php

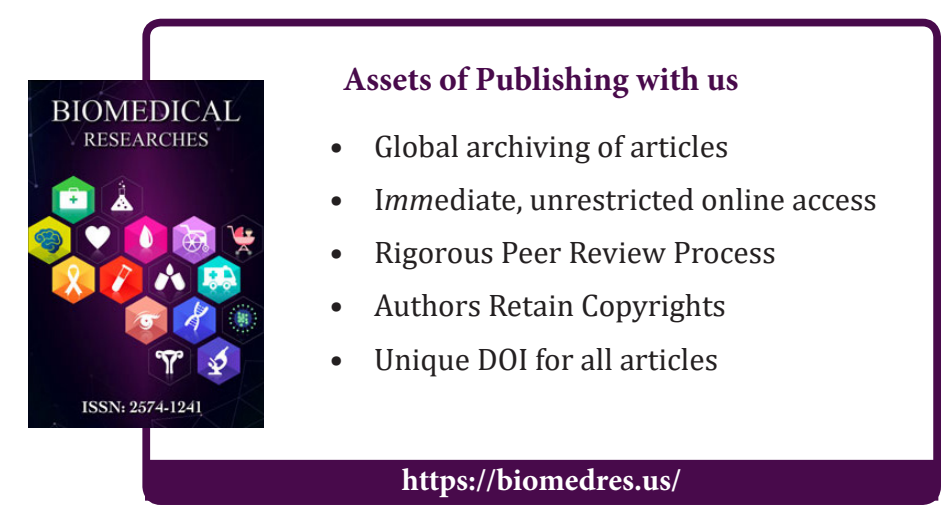

